\title{
Is Earnings Management a Technique to Reduce Cost of Capital? Exploratory Study on Indian Companies
}

\author{
Archana Patro \\ Institute for Financial Management and Research, Sri City, India \\ A. Kanagaraj \\ Xavier School of Management, Jamshedpur, India
}

\begin{abstract}
Earnings management has attracted lots of academicians towards the research due to the emerging frauds and downfall of great corporate giants of the world. Mainly earnings measurement is based on the accounting estimates which managers can easily manipulate for their self-interest. The study investigates the relationship between cost of capital and the earnings measurement for the Indian firms. Measurement of earnings is mostly computed by taking either discretionary accruals (DAC) or non-discretionary accruals (NDAC). Present study has used Dechow, Sloan, and Sweeney (1995) model for earnings measurement and for analyzing the results. Panel data regression has also been used. Findings of the study conclude that DAC has a significant influence on cost of capital, but NDAC has no influence.
\end{abstract}

Keywords: earnings management, discretionary accruals, non-discretionary accruals, cost of capital, India

\section{Introduction}

Accurate financial information is very crucial for making investment decisions. But managers in a firm are involved in earnings management. As per Healy and Wahlen (1998, p. 368), "Earnings management occurs when managers use judgment in financial reporting and in structuring transactions to alter financial reports to either mislead some stakeholders about the underlying economic performance of the company, or to influence contractual outcomes that depend on reported accounting numbers".

Schipper (1989) defined earnings management as the purposeful intervention in the external financial reporting process with the intent of private gains. Managers of firms face the pressure of certain earnings benchmark. Meeting the targeted earnings and lower cost of capital is associated with high reputation (Kasznik \& McNichols, 2002; Brown \& Caylor, 2005). If they are reporting earnings below their benchmark, they suffer a huge harm (Skinner \& Sloan, 2002) and which in turn reduces the executive compensation (Matsunaga \& Park, 2001). So, managers manipulate the earnings to meet their required objective. The study on earnings management is very important for a country like India due to the rising accounting frauds in the country. India is one of the fastest emerging economies in Asia and is attracted by a large number of foreign institutional investors for investments. This trend of flow of capital from outside investors can be

Archana Patro, assistant professor, Faculty (Finance \& Accounting), Institute for Financial Management and Research. Email: archana.patro06@gmail.com.

A. Kanagaraj, associate professor, Faculty (Finance \& Accounting), Xavier School of Management. 
sustained if the investors are provided protection against these manipulation and frauds. Moreover, there is a huge segment of retail investors in India who are fully depended on the published financial reports for making their investment decisions; hence, regulators have the duty to protect the interest of these investors.

Management of earnings is probable due to the flexibility provided by GAAP (Generally Accepted Accounting Principles) for interpreting the accounting event differently (Teoh, Welch, \& Wong, 1988). Generally, such earnings management can be done through either the manipulation of discretionary accruals (DAC) or the manipulation of real activities. The present study takes into account both methods to evaluate the earnings management by Indian firms. So, accruals are used as a substitute for earnings management in the present study. From the two types of accruals available, non-discretionary accruals (NDAC) have no control on managers for delaying or deleting any transaction (Mashayekhi, S. Mehrani, K. Mehrani, \& Karami, 2006) but DAC is a type of accruals which managers can influence by reporting the earnings near to their favored earnings for getting better incentives in the form of reward from the top management (Dechow et al., 1995; Shuto, 2007). Cost of capital is used for making most of the financial and management decisions (Jalali, 2006). Cost of capital is used by the managers for making capital budgeting decisions, optimum capital structure decisions, and working capital management decisions, etc. (Nasirpour, 2000). Cost of capital is defined as the expected rate of return which leads to stabilizing the value of economic unit. If it is lower than the cost of capital, it is interpreted as reduction in economic unit. Hence, firms use different strategies to reduce the cost of capital and try their best to increase the expected rate of return. The present paper tries to investigate whether there is any relationship between earnings management and cost of capital. The study made an attempt to explore the following research question: Do firms in India use earnings management as a tool to reduce the cost of capital? Empirical literature reveals that DAC can be used as a tool for earnings management.

\section{Review of Literature}

There are numerous studies on earnings management. Investigating earnings management is one of the prime challenges for researchers as it is mostly invisible (Dechow, Hutton, Kim, \& Sloan, 2012). Prior literature has examined earnings management through different means such as accounting classification used by Athanasakou, Strong, and Walker (2007), extraordinary items by Barnea, Ronen, and Sadan (1976), through stock dividends (Bartov, 1993), methods of depreciation by Archibald (1967), research and development expenditure by Dascher and Malcom (1970) and finally through DAC by Dechow et al. (1995). Isolating discretionary from non-discretionary helps in detecting better earnings management. Dechow et al. (1995) revealed that when DAC increases, it is more likely that earnings management will also increase. As a result, firm's financial situation improves which leads to reduction in the cost of capital. Peasnell, Pope, and Young (2005), in their study, have examined that in England, the number of indirect managers has an inverse relationship with the possibility of abnormal accruals management to avoid decreasing losses. Marquardt and Wiedman (2004) study has shown evidence of low relevance of earnings due to earnings management and this reduction is greater for discretionary components of earnings than non-discretionary ones. Companies involved in multi activities have less earnings management (Charoenwong \& Jiraporn, 2009). Managers use DAC to reduce the variations in the earnings (Ghosh \& Olsen, 2009). The relationship between earnings forecast characteristics and cost of equity capital was explained by Rakow (2010) which showed that forecast that predicts a loss is associated with higher cost of equity capital level and vice versa. 
Rahmani and Fallahnezhad (2010) stated that firm size and ratio of interest debts depend on the DAC. Linck, Netter, and Shu (2013) established that financially constrained firms have higher DAC. Although there are numerous studies on earnings management in different countries, we still find limited studies in the Indian context. Shen and Chih (2005) study provides evidence of earnings management in Indian banking industry. Further, Chipalkatti, Le, and Rishi (2007) detected that banks with low profitability are mainly indulged in earnings management. J. Sarkar, S. Sarkar, and Sen (2008) found a negative relationship between board independence and earnings management. Rudra and Bhattacharjee (2012) found that companies after adopting IFRS have low earnings management. But none of these studies have found any relationship between the earnings management and cost of capital of the firm which will be investigated in the present study. The paper has made an attempt to answer the following research question: Do Indian firms use earnings management as a technique to reduce the cost of capital? And if there is a relation further it will try to explore its relationship with the type of accruals, either it is DAC or due to NDAC.

The following hypotheses were tested for the firms listed in the Bombay Stock Exchange (BSE):

$\mathrm{H}_{1}$ : There is a relation between DAC and weighted average cost of capital (WACC) for firms listed at BSE.

$\mathrm{H}_{2}$ : There is a relation between NDAC and WACC for firms listed at BSE.

\section{Research Methodology}

\section{Sample Selection}

Sample size for the study includes all the firms listed at BSE from the Prowess database for the period of 2003-2013. For the purpose of uniformity, only firms satisfying the following criteria were selected: Firms should have complete information. It should be active during the period of our study. Firms without complete information were excluded from the sample. Finally, we have 14,250 firm-year observations.

\section{Data and Measurement}

In the following section, we have described the methods of measuring earnings management through NDAC and DAC. Managers use these techniques for manipulating the firm's earnings. Jones (1991) proposed a model aimed at capturing the effects of changes in the accruals. The model identifies that the factors such as change in asset size and property, plant, and equipment (PPE) are the determining factors for NDAC. Sales revenue can be used as a proxy for event that generates NDAC, whereas PPE controls for the depreciation expense of NDAC. Dechow et al. (1995) identified major limitations with this model and came out with their modified version of Jones model. This model is widely accepted for computing and detecting earnings management. Hence, the present study has taken Dechow et al. (1995) model to investigate the association between earnings management and cost of capital. The different variables used in the present study are explained below.

Independent variable. Earnings management is defined and measured as follows (Salteh, Valipour, \& Zarenji, 2012):

$$
\mathrm{TACC}_{i, t}=\Delta C A_{i, t}-\Delta C L_{i, t}-\Delta \operatorname{Cash}_{i, t}+\Delta S T D E B T_{i, t}-\operatorname{DEPTN}_{i, t}
$$

where:

$\Delta C A_{i, t}=$ Change in current assets during period $t ;$ 
$\Delta C L_{i, t}=$ Change in current liabilities during period $t$

$\Delta \operatorname{Cash}_{i, t}=$ Change in cash and cash equivalents during period $t$

$\triangle S T D E B T_{i, t}=$ Change in the current maturities of long-term debt and other short-term debts included in current liabilities during period $t$;

$\triangle D E P T N_{i, t}=$ Depreciation and amortization expense during period $t$.

DAC and NDAC as independent variables are separated from total accruals by using the Dechow et al. (1995) model.

Total accruals (1) and NDAC (2) using the Dechow et al. (1995) model of relationship are calculated as follows:

$$
\begin{gathered}
\operatorname{TA}_{i, t} / A_{i, t-1}=\alpha_{0}\left(1 / A_{i, t-1}\right)+\alpha_{1}\left(\Delta R E V_{i, t-1}-\Delta R E C_{i, t-1}+\Delta I N V_{i, t-1} / A_{i, t-1}\right) \\
+\alpha_{2}\left(P P E_{i, t} / A_{i, t-1}\right)+€_{i, t} \\
N D A C_{i, t}=\alpha_{0}\left(1 / A_{i, t-1}\right)+\alpha_{1}\left(\Delta R E V_{i, t-1}-\Delta R E C_{i, t-1}+\Delta I N V_{i, t-1} / A_{i, t-1}\right)+\alpha_{2}\left(P P E_{i, t} / A_{i, t-1}\right)
\end{gathered}
$$

where:

$T A_{i, t}=$ Total accruals for firm $i$ in year $t$ divided by total assets for firm $i$ at the end of year $t-1$;

$\triangle R E V_{i, t-1}=$ Change in revenue for firm $i$ in year $t$ divided by total assets for firm $i$ at the end of year $t-1$;

$\triangle R E C_{i, t-1}=$ Change in net receivable for firm $i$ in year $t$ divided by total assets for firm $i$ at the end of year $t-1$;

$\Delta I N V_{i, t-1}=$ Change in inventories for firm $i$ in year $t$ divided by total assets for firm $i$ at the end of year $t-1$;

$P P E_{i, t}=$ Property, plant, and equipment for firm $i$ in year $t$ divided by total assets for firm $i$ at the end of year $t-1$.

Finally, DAC (3) is achieved from the difference between total accruals and NDAC:

$$
D A C_{i, t}=T A_{i, t} / A_{i, t-1}-N D A C_{i, t}
$$

Dependent variable: WACC. In this study, the WACC as the dependent variable is calculated as follows:

$$
W A C C=\left(L_{t} / L_{t}-E_{t}\right) * K_{d}(1-t)+\left(E_{t} / L_{t}+E_{t}\right) * K_{e}
$$

where:

$L_{t}$ : Total interest debts of the $i$ th firm in period $t$;

$E_{t}$ : Total shareholders' equity of the ith firm in period $t$;

$K_{d}$ : The interest rate of participation bonds announced by the central bank.

$K_{e}$ is calculated based on Gordon model:

$$
K_{e}=\left[D_{0}(1+g) / P_{0}\right]+g
$$

where:

$D_{0}$ : The divided earnings per share at the end of previous year;

$P_{0}$ : Share price of the $i$ th firm at the beginning of financial period $t$;

$g$ : Growth rate of earnings (dividends geometric mean).

Control variables. The relationship between earnings management and the WACC may be affected by the firm-specific characteristics. Hence, the two variables firm size and the ratio of book value to market value 
(BV/MV) of equity are controlled in the model. Watts and Zimmerman (1978) have proved that large size firms have greater incentive to decrease the earnings as they are more subject to scrutiny from financial analysts and investors and hence they have a huge influence on the stock market. Firm size can be reported as sale logarithm of the company at the end of financial period. Based on Nissim and Penman (2001), BV/MV is found through dividing the book value of the equity in the past year by the market value of the equity.

\section{Empirical Results}

To test the hypotheses of the study, the following analysis such as descriptive statistics, correlation and panel data analysis has been done.

Table 1

Descriptive Statistics

\begin{tabular}{lccccc}
\hline & $N D A C$ & $D A C$ & WACC & SIZE & BV/MV \\
\hline$N$ & 14,250 & 14,250 & 14,250 & 14,250 & 14,250 \\
Mean & 1.24927 & -3.64094 & 34.1826 & 3.47449 & 2.18478 \\
SD & 184.742135 & 368.07064 & $2,518.1248$ & 1.069371 & 6.624499 \\
Variance & $34,129.656$ & $135,475.99$ & $6,340,952.4$ & 1.144 & 43.884 \\
Skewness & -66.961 & -85.632 & 114.804 & 0.126 & 10.257 \\
Kurtosis & $5,509.82$ & $10,050.314$ & $13,191.538$ & -0.235 & 133.003 \\
Minimum & $-16,685.941$ & $-40,072.95$ & -868.248 & -1 & 0.002 \\
Maximum & $2,947.19$ & $14,865.941$ & $289,358.59$ & 6.776 & 100 \\
\hline
\end{tabular}

Table 1 represents the descriptive statistics. The mean values for DAC and NDAC in Dechow et al. (1995) model and WACC are represented by $-3.64094,1.24927$, and 34.1826 , respectively.

The correlation result between variables is presented in Table 2 .

Table 2

Pearson Correlation Test

\begin{tabular}{llllll}
\hline & & NDAC & $D A C$ & SIZE & BV/MV \\
\hline \multirow{2}{*}{ WACC } & Pearson correlation & 0.006 & $-0.0325^{*}$ & 0.003 & 0.006 \\
& Significance & 0.530 & 0.079 & 0.770 & 0.498 \\
\hline
\end{tabular}

Note. " denotes coefficients with a $p$-value of 0.1 or lower.

From the results, it is evident that there exists a significant and inverse correlation between DAC and cost of capital. But the same is not observed for NDAC.

Testing results of $\mathrm{H}_{1}$ as measured by Dechow et al. (1995) model are presented in Table 3.

Table 3

Multivariate Linear Regression (Relation Between DAC and WACC)

\begin{tabular}{lllll}
\hline \multirow{2}{*}{ Adjusted $R$ square } & $R$ square & Durbin-Watson & \multicolumn{2}{c}{ ANOVA } \\
\cline { 3 - 5 } & & & $F$ & Sig. \\
\hline 0.007 & 0.006 & 2.012 & 23.745 & 0.00 \\
\hline Hypothesis & Independent variables & Beta & -5.466 & Sig. \\
\hline $\mathrm{H}_{1}$ & $D A C$ & -0.001 & 8.434 & 0.00 \\
Control variable & SIZE & 0.082 & 0.234 & 0.00 \\
Control variable & $B V / M V$ & 0.002 & & 0.815 \\
\hline
\end{tabular}


Table 3 shows the increase in multiple correlation coefficients after adding variables. Also, the coefficient of determination is 0.006 which is an indication of relationship between the variables. Durbin-Watson statistic is 2.012 , indicating a serial correlation between variables. The results also indicate that the coefficient of variables before and after the addition of variables, using the $F$-statistic at the confidence level of $95 \%$, is significant.

Regarding what we observed in Table 3, The ANOVA column sig. is less than 5\% but sig. of NDAC variable is more than $5 \%$ in Table 4 . That alone shows that there is no significant relationship between NDAC and WACC $\left(\mathrm{H}_{2}\right.$ is rejected).

Table 4

Multivariate Linear Regression (NDAC and WACC)

\begin{tabular}{|c|c|c|c|c|}
\hline \multirow{2}{*}{ Adjusted $R$ square } & \multirow{2}{*}{$R$ square } & \multirow{2}{*}{ Durbin-Watson } & \multicolumn{2}{|c|}{ ANOVA } \\
\hline & & & $F$ & Sig. \\
\hline 0.006 & 0.007 & 2.012 & 23.882 & 0.00 \\
\hline Hypothesis & Independent variables & Beta & $t$ & Sig. \\
\hline $\mathrm{H}_{2}$ & $N D A C$ & 0.006 & 0.645 & 0.519 \\
\hline Control variable & SIZE & 0.082 & 8.437 & 0.00 \\
\hline Control variable & $B V / M V$ & 0.002 & 0.232 & 0.817 \\
\hline
\end{tabular}

\section{Conclusion}

The study explores the relationship between earnings management and cost of capital in 840 firms listed at BSE in around 10-year period from the year 2003 to 2013.

Results of the study indicate a negative relationship between WACC and DAC. It can be interpreted that firms with poor performance have more incentives for earnings management. The managers in these firms try to overstate the earnings to avoid undervaluation of their stock and hence reduce the WACC for the same. Study also explores the relationship between NDAC and earnings management. Results have indicated no significant relationship between them. So, it can be concluded that managers cannot exploit the NDAC to inflate the earnings. The findings of the study have important implications for regulators. Regulators can play an important role by enforcing appropriate standards and disclosure requirements which can reduce the motives for earnings management.

\section{References}

Archibald, T. R. (1967). The return to straight-line depreciation: An analysis of a change in accounting method. Journal of Accounting Research, 5, 164-180.

Athanasakou, V. E., Strong, N. C., \& Walker, M. (2007). Classificatory income smoothing: The impact of a change in regime of reporting financial performance. Journal of Accounting and Public Policy, 26(4), 387-435.

Barnea, A., Ronen, J., \& Sadan, S. (1976). Classificatory smoothing of income with extraordinary items. The Accounting Review, 51(1), 110-122.

Bartov, E. (1993). The timing of asset sales and earnings manipulation. The Accounting Review, 68(4), 840-855.

Brown, L. D., \& Caylor, M. L. (2005). A temporal analysis of quarterly earnings thresholds: Propensities and valuation consequences. The Accounting Review, 80(2), 423-440.

Charoenwong, C., \& Jiraporn, P. (2009). Earnings management to exceed thresholds: Evidence from Singapore and Thailand. Journal of Multinational Financial Management, 19(3), 221-236.

Chipalkatti, N., Le, Q. V., \& Rishi, M. (2007). Portfolio flows to emerging capital markets: Do corporate transparency and public governance matter? Business and Society Review, 112(2), 227-249. 
Dascher, P. E., \& Malcom, R. E. (1970). A note on income smoothing in the chemical industry. Journal of Accounting Research, 8(2), 253-259.

Dechow, P. M., Hutton, A. P., Kim, J. H., \& Sloan, R. G. (2012). Detecting earnings management: A new approach. Journal of Accounting Research, 50(2), 275-334.

Dechow, P. M., Sloan, R. G., \& Sweeney, A. P. (1995). Detecting earnings management. The Accounting Review, 70(2), $193-225$.

Ghosh, D., \& Olsen, L. (2009). Environmental uncertainty and managers' use of discretionary accruals. Accounting, Organizations and Society, 34(2), 188-205.

Healy, P. M., \& Wahlen, J. M. (1999). A review of the earnings management literature and its implications for standard setting. Accounting Horizons, 13(4), 365-383.

Jalali, F. (2006). Investigation of effective factors on cost of capital in companies listed at Tehran Stock Exchange (M.A thesis, Alzahra University). [in Persian].

Jones, J. J. (1991). Earnings management during import relief investigations. Journal of Accounting Research, 29(2), 193-228.

Kasznik, R., \& McNichols, M. F. (2002). Does meeting earnings expectations matter? Evidence from analyst forecast revisions and share prices. Journal of Accounting Research, 40(3), 727-759.

Linck, J. S., Netter, J., \& Shu, T. (2013). Can managers use discretionary accruals to ease financial constraints? Evidence from discretionary accruals prior to investment. The Accounting Review, 88(6), 2117-2143.

Marquardt, C. A., \& Wiedman, C. I. (2004). The effect of earnings management on the value relevance of accounting information. Journal of Business Finance \& Accounting, 31(3-4), 297-332.

Mashayekhi, B., Mehrani, S., Mehrani, K., \& Karami, G. R. (2006). The role of discretionary accruals in earnings management of listed companies in Tehran Stock Exchange (TSE). The Iranian Accounting and Auditing Review, 12(42), 61-74.

Matsunaga, S. R., \& Park, C. W. (2001). The effect of missing a quarterly earnings benchmark on the CEO's annual bonus. The Accounting Review, 76(3), 313-332.

Nasirpour, M. (2000). The investigate effects of firm size on cost of capital in companies listed at Tehran Stock Exchange (M.A thesis, Shahid Beheshti University). [in Persian].

Nissim, D., \& Penman, S. H. (2001). Ratio analysis and equity valuation: From research to practice. Review of Accounting Studies, 6(1), 109-154.

Peasnell, K. V., Pope, P. E., \& Young, S. (2005). Board monitoring and earnings management: Do outside directors influence abnormal accruals. Journal of Business Finance \& Accounting, 32(7-8), 1311-1346.

Rahmani, A., \& Fallahnezhad, F. (2010). Effect of accrual quality on the cost of common stock. Journal of Financial Accounting Research, 2(3), 17-30.

Rakow, K. C. (2010). The effect of management earnings forecast characteristics on cost of equity capital. Advances in Accounting, 26(1), 37-46.

Rudra, T., \& Bhattacharjee, D. (2012). Does IFRS influence earnings management? Evidence from India. Journal of Management Research, 4(1), 1-13.

Salteh, H. M., Valipour, H., \& Zarenji, S. S. N. S. (2012). Investigating the relationship between earnings management and weighted average cost of capital (WACC). Business and Management Review, 1(12), 28-38.

Sarkar, J., Sarkar, S., \& Sen, K. (2008). Board of directors and opportunistic earnings management: Evidence from India. Journal of Accounting, Auditing \& Finance, 23(4), 517-551.

Schipper, K. (1989). Commentary on earnings management. Accounting Horizons, 3, 91-102.

Shen, C. H., \& Chih, H. L. (2005). Investor protection, prospect theory, and earnings management: An international comparison of the banking industry. Journal of Banking \& Finance, 29(10), 2675-2697.

Shuto, A. (2007). Executive compensation and earnings management: Empirical evidence from Japan. Journal of International Accounting, Auditing and Taxation, 16(1), 1-26.

Skinner, D. J., \& Sloan, R. G. (2002). Earnings surprises, growth expectations, and stock returns or don't let an earnings torpedo sink your portfolio. Review of Accounting Studies, 7(2-3), 289-312.

Teoh, S. H., Welch, I., \& Wong, T. J. (1998). Earnings management and the long-run market performance of initial public offerings. Journal of Finance, 53(6), 1935-1974.

Watts, R. L., \& Zimmerman, J. L. (1978). Towards a positive theory of the determination of accounting standards. The Accounting Review, 53(1), 112-134. 